\title{
Societal trust and the economic behavior of nonprofit organizations
}

\author{
Robert Felix** \\ University of Baltimore \\ Merrick School of Business \\ rfelix@ubalt.edu \\ Greg Gaynor \\ University of Baltimore \\ Merrick School of Business \\ ggaynor@ubalt.edu \\ Mikhail Pevzner* \\ University of Baltimore \\ Merrick School of Business \\ mpevzner@ubalt.edu \\ Jan L. Williams \\ University of Baltimore \\ Merrick School of Business \\ jwilliams@ubalt.edu
}

September, 2017

\begin{abstract}
* Dr. Mikhail Pevzner served as an academic fellow at the U.S. Securities and Exchange Commission during 2016-17 academic year. The Securities and Exchange Commission, as a matter of policy, disclaims responsibility for any private publication or statement by any of its employees. The views expressed herein are those of the author and do not necessarily reflect the views of the Commission or of Dr. Pevzner's colleagues upon the staff of the Commission.

**Corresponding Author, 1420 North Charles Street, Baltimore, MD 21201. Mikhail Pevzner gratefully acknowledges the assistance of EY Chair in Accounting at the University of Baltimore.
\end{abstract}




\title{
Societal trust and the economic behavior of nonprofit organizations
}

\begin{abstract}
:
This study explores the impact of societal trust on the economic behavior of nonprofit organizations. Although prior studies reveal that trust has a positive impact on the economic behavior of for-profit firms, the institutional differences between the two organization types make it unclear whether trust plays a similar role in nonprofits. Our results show that nonprofits operating in higher trust areas are more likely to overspend on administrative expenses. This positive relationship between trust and overspending is primarily driven by service organizations, as opposed to public charities. Moreover, within service organizations, we find that the positive trust-administrative overspending association is most prevalent in situations of weaker monitoring or governance. Additional tests show trust has a similar impact on excess compensation and abnormal accruals in service organizations. Overall, our findings suggest that trust may provide opportunities for nonprofit managers, particularly in service-oriented organizations, to engage in opportunistic behavior that may be exacerbated by weaker forms of oversight.
\end{abstract}

Key Words: Trust, nonprofit organizations, opportunistic spending, administrative expenses

Data Availability: Data are available from commercial and non-commercial sources identified in the text.

JEL Classification: L30, M40, M4 
Why are non-profits so vulnerable? In a word, trust. These organizations are often based on the charity, faith and goodwill of fellow citizens. The organizations strive to create and protect a culture of trust that is oftentimes lacking at for-profit companies, and therefore don't always have the formal set of internal controls in place to guard against fraud that might otherwise be expected. ${ }^{l}$

\section{Introduction}

Societal generalized trust (hereafter "trust") can serve as a key tool to reduce financial frictions and agency problems. Trust between agents can enhance successful relational exchanges (Morgan and Hunt, 1994). To that end, prior research finds that higher trust is associated with an array of positive outcomes, such as higher levels of earnings quality and greater credibility of earnings news (Pevzner et al., 2015; Wei and Zhang, 2015) as well as lower levels of corporate misconduct (Dong et al., 2016). However, an underlying assumption is that trust is usually accompanied by enforcement mechanisms, which are discussed below in further detail (Robinson and Robinson, 2015; Knechel et al., 2017). In the nonprofit setting, enforcement mechanisms are generally weaker than those in the for-profit environment. Therefore, institutional differences between the for-profit and nonprofit settings make it unclear ex-ante whether trust would have a similar impact on nonprofits. Accordingly, we examine the impact of trust on nonprofit managerial opportunism in an attempt to shed light on the role of trust on managerial behavior in the nonprofit setting.

Societal trust can be expected to play a more positive exchange-enhancing role in "repeated game" long-term relationships between agents and principals (Garbarino and Johnson, 1999). In the for-profit setting, shareholders, as residual claimants, have an incentive to monitor and discipline managers for violating trust. Consequently, for-profit managers understand that

\footnotetext{
1 "Preventing Fraud: Tips for Nonprofit Organizations," Cbiz.com, https://www.cbiz.com/insightsresources/details/articleid/1484/preventing-fraud-tips-for-nonprofit-organizations-article (September 20, 2012)
} 
exploiting trust can lead to long-term consequences of lower stock prices and/or reduced employment (Fama \& Jensen, 1983a \& b). Thus, shareholders can use the stock market as a disciplining mechanism. In the for-profit setting, external enforcement mechanisms, such as the Securities and Exchange Commission (SEC) and active class-action shareholder litigation, are extra layers of discipline that enforce the principal-agent trust. Therefore, in the for-profit environment, disciplining mechanisms accompany the direct-monitoring relationship between principal and agent.

In the nonprofit environment, the principals are the donors and, unlike shareholders, they are not residual claimants (Desai and Yetman, 2015). Donors are commonly inspired to give because of the "warm glow" surrounding a nonprofit's mission (Becker, 1974; Andreoni, 1990). Since donors do not attempt to preserve their own wealth, their incentives for monitoring nonprofit managers (agents) are generally weaker than those of shareholders. In addition, stringent enforcement mechanisms such as the SEC and shareholder litigation, as well as an equivalent market disciplining mechanism, are largely absent in the nonprofit setting. This relative lack of nonprofit monitoring and enforcement may mean that, compared to their forprofit counterparts, nonprofit managers have less incentive to respect the trust relationship.

Using 93,117 observations of nonprofit entities from the National Center for Charitable Statistics (NCCS) database for the period between 1986 and 2012, we examine the effect of trust on the likelihood of overspending on administrative expenses. Overspending on administrative expenses indicates inefficient resource allocation (Baber et al., 2002; Trussel et al., 2007), which can suggest managerial opportunism. We measure trust as the percentage of people in a given 
U.S. geographic region who consider themselves to be trusting, according to surveys conducted by the World Values Survey. ${ }^{2}$

Our primary result reveals that nonprofits operating in higher trust areas are more likely to overspend on administrative expenses, suggesting that managerial opportunism can prevail in response to high trust. In other words, the institutional make-up of nonprofits enables managers to overspend on administrative expenses in the presence of higher trust. Our main result concerns the average effect among nonprofits. However, nonprofits differ in their mission, operation, and relationship with donors. Accordingly, our results vary by nonprofit type. Though there are a wide variety of nonprofits (Yetman and Yetman, 2012a), a broad distinction can be made based upon whether the donor receives a service from the nonprofit (Hansmann, 1980).

Using this distinction, we examine the effect of trust on two nonprofit categories: service organizations and public charities. Consistent with Kitching et al. (2012), our public charities category excludes art and culture nonprofits, religious organizations, and nonprofits in the education or medical field. These excluded organizations, where donors receive a service or benefit from the nonprofit, are categorized as service organizations. Donors to service organizations are likely to be actively involved with the nonprofit on a regular basis, which can "build trust and obviate the need for a formal feedback mechanism" (Gordon and Khumawala, 1999, p.48). In such case, these donors resemble consumers. As long as donors are satisfied with their service from the nonprofit, they may be less inclined to monitor (Gordon and Khumawala, 1999). Thus, while donors may trust the service organizations, they also may have less incentive to properly monitor those nonprofits, thereby creating a situation where trust could be exploited.

\footnotetext{
${ }^{2}$ More details on this survey are provided in Section 3.3.
} 
In public charities, which make up the remaining nonprofit entities, the donor does not receive the service. This creates a clear distinction between donor and service recipient (Balsam and Harris, 2014). Compared with donors to service organizations, donors to public charities are likely to be more reliant on formal mechanisms, such as financial information, to ensure that their donations are properly expended. We find that the association between trust and overspending is driven by service organizations, as opposed to public charities. This is consistent with the view that trust can be exploited in service organizations because of the lack of proper monitoring.

Service organizations appear to overspend on administrative expenses in the presence of higher trust due to a relative lack of monitoring by their donors. As such, we perform additional testing to determine whether the presence of other potential monitoring mechanisms has an impact on this behavior. In the additional cross-sectional tests, we find that service organizations are most likely to overspend on administrative expenses in the presence of high trust when there is weaker governance, less external monitoring, less competition, or lower information quality. Overall, we suggest that weaker forms of oversight help enable opportunistic behavior when there is high trust.

In additional analysis, we find that trust is positively associated with abnormal accruals and excess compensation in service organizations. This is consistent with the results of Balsam and Harris (2014), who suggest that service organization donors are less likely to react negatively to the excessive compensation of service organization executives. Overall, this provides support for our main finding of managerial opportunism in the presence of higher trust, which is contrary to what has been observed in "for profit" literature (Hilary and Huang, 2015). Our results are robust to alternate definitions for service organizations and public charities as well as to an industry- 
adjusted calculation of the trust variable. We also find that the trust-overspending association for service organizations is present only for education and religious organizations.

Our study advances the literature by exploring the association between trust and the economic behavior of managers in the nonprofit sector. To the best of our knowledge, this is the first study to examine and provide an important understanding of the impact of societal trust in the nonprofit sector. By documenting that trust is associated with overspending on administrative expenses, our study suggests that trust plays a different role in the nonprofit setting than in the for-profit environment. Moreover, our study also reveals that trust does not affect all nonprofits in the same way. Specifically, we document that service organizations are more likely to behave opportunistically in high-trust environments than are public charities. Although we attribute this to the potentially different principal-agent relationship in these two nonprofit types, we also note there is variation even among the service organizations. To that end, education and religious institutions were the service organizations most likely to overspend in the presence of high trust. Furthermore, we document that weaker oversight is associated with opportunistic behavior in the presence of higher trust. This suggests that increased monitoring may help reduce a nonprofit's likelihood of overspending when trust is high (Robinson and Robinson, 2015).

Our paper proceeds as follows. Section 2 provides hypothesis development. In Section 3, we describe our research design and sample. Section 4 describes our empirical results and Section 5 concludes with a discussion of our results and future research opportunities.

\section{Hypothesis development}

Recent research has emphasized the potential benefits of trust in for-profit capital markets. The broad theme of this research is that higher societal trust is associated with lower levels of 
transaction and agency costs. Higher-trust societies experience stronger economic growth and GDP (Zak and Knack, 2001; Knack and Keifer, 1997), experience lower levels of corruption (Aghion et al., 2010), and have lower levels of earnings management and more credible reported earnings (Nanda and Wysocki, 2013; Pevzner et al., 2015). In addition, higher-trust societies have more efficient trading and more intensive levels of cross-border merger and acquisition activity (Ahern et al., 2015) as well as a higher perceived value of financial audits (Knechel et al., 2017).

Although the empirical evidence suggests trust has positive effects on firms' economic behavior in the for-profit environment, it is unclear whether this applies to nonprofits, specifically as it relates to managerial behavior. On the one hand, it is reasonable to suggest that nonprofit managers have incentive to preserve donors' trust just as for-profit managers have reasons to sustain the trust of investors. Because nonprofits rely upon donations, nonprofit managers must work to build trust by faithfully fulfilling their mission and maximizing the welfare of their recipients, instead of maximizing profits (Krishnan et al. 2006). On the other hand, however, institutional differences between the for-profit and nonprofit settings may mean that the benefits for nonprofit managers of violating trust through activities, such as overspending, may outweigh the costs.

In the for-profit setting, investors (principals) are residual claimants and, thus, have a strong incentive to monitor and discipline managers (agents) for violating trust. For-profit managers who exploit trust can be expected to face the long-term consequences of lower stock prices and/or reduced employment (Fama \& Jensen, 1983 a,b). Additionally, the stock market acts as a disciplining mechanism on for-profit managers who violate trust. 
In the nonprofit setting, agency problems may be less effectively remedied due to weaker enforcement and monitoring mechanisms (Krishnan et al., 2006). Donors, as the principals, typically contribute to nonprofits because of the praise, respect and recognition received in doing so (Becker, 1974; Andreoni, 1990), as opposed to seeking a purely monetary return on their investment as do for-profit investors. Thus, donors may not feel the need to closely monitor management's use of their contribution, thereby producing an environment more conducive to opportunistic managerial behavior in the form of overspending. In addition, donors do not have their own version of a for-profit stock market to use as a disciplining mechanism.

Besides being subject to relatively less monitoring by principals, nonprofit managers also face a less stringent regulatory environment than do their for-profit counterparts (Lloyd et al., 2006). Since nonprofits do not issue stock to the public, they do not fall under the purview of the SEC, the Sarbanes-Oxley Act (SOX) or the Public Companies Accounting Oversight Board (Neely, 2011; Archambeault et al., 2015). ${ }^{3}$ Nonprofits are required to report financial information on Form 990 to the Internal Revenue Service (IRS), ${ }^{4}$ and can be subject to penalties for IRS violations (Grunewald, 2008). However, such abuses do not always result in prosecutions. Altogether, the relative lack of external discipline and monitoring mechanisms in the nonprofit setting suggests that nonprofit managers, compared with for-profit managers, may face less severe repercussions for violating the trust of their principals (donors) by acting opportunistically (Atuahene-Gima and Li, 2002). Accordingly, we suggest that, on average,

\footnotetext{
${ }^{3}$ Grunewald (2008) reports that some nonprofits voluntarily committed to observing some provisions of SOX. Blodgett and Melconian (2012) document that several states adopted statutes similar to SOX with respect to nonprofits; however, there is variability in terms of how these statutes are applied.

${ }^{4}$ Nonprofits with gross receipts greater than or equal to $\$ 200,000$ or total assets greater than or equal to $\$ 500,000$ at the end of the tax year are required to file Form 990. Since our sample is based on information from Form 990, all nonprofits in our sample would be subject to any Form 990-related enforcement.
} 
higher societal trust is associated with more opportunistic behavior by nonprofit managers. This leads us to the following hypothesis:

H1: Societal trust is positively associated with opportunistic behavior by nonprofit managers.

If $\mathrm{H} 1$ is true, the question arises as to whether such opportunistic behavior would be prevalent among all nonprofits. To explore this, we classify nonprofits as either service organizations or public charities (Hansmann, 1980). For service organizations, the donor is also the ultimate beneficiary of goods or services. However, for public charities, this is not the case.

Donors to service organizations are likely to be actively involved with the nonprofit on a regular basis. This 'closeness' to nonprofits can build relationships and trust which mitigates the need for formal financial mechanisms (Gordon and Khumawala, 1999). Thus, these donors may be less inclined to monitor if they are satisfied with their service from the nonprofit. In that sense, donors to service organizations resemble consumers since "consumers do not ask for financial statements" before their purchase (Gordon and Khumawala, 1999, p.49). Consistent with this view, Balsam and Harris (2014) find that donors of service organizations are less likely to react negatively to disclosures of excessive executive compensation. Thus, while donors may trust the service organizations, they also may have lower incentive to properly monitor these nonprofits, thereby potentially creating a situation where trust could be exploited.

If managers of service organizations expect to be monitored less, they may be more likely to engage in opportunistic behavior. Robinson and Robinson (2015) suggest that enforcement, monitoring, and trust are complements. In other words, if trust is unaccompanied by monitoring and/or enforcement, it eventually leads to violations of trust. Because a service-type nonprofit may be characterized by an especially low level of donor oversight, there may exist an especially 
high level of managerial opportunism in the presence of trust. This leads us to the following hypothesis:

H2: The positive association between societal trust and opportunistic behavior is driven by service organizations.

\section{Empirical Design}

\subsection{Sample Selection}

We compile nonprofit data from the Statistics of Income (SOI) file made available by the National Center for Charitable Statistics (NCCS) for the years 1986-2012. The SOI data are based on Form 990 that nonprofit organizations file with the IRS. These include all organizations with total assets of at least $\$ 10$ million for years before 2000 and at least $\$ 30$ million in assets for years 2000 and after. The data also include a stratified sample of smaller organizations. The SOI database captures over 90 percent of all nonprofit revenues in a given year (Yetman and Yetman, 2012b).

We present our sample selection process in Table 1. As indicated, we start with 336,821 nonprofit-year observations then remove observations with less than $\$ 1,000$ of total expenses, total revenue, total assets, or total program expense (Yetman and Yetman, 2013). Because nonprofits that report little to no advertising or administrative costs may be either close to being defunct or misreporting that activity (Kitching et al., 2012), we remove observations with less than $\$ 1,000$ of total fundraising or administrative expense. We then eliminate observations where the sum of fundraising, administrative, and program expenses do not equal total expenses since this may indicate that Form 990 has been improperly completed (Kitching et al., 2012). Our final sample yields 93,117 nonprofit-year observations. 
We define service organizations as nonprofits where the donor receives the service of the nonprofit and public charities as those where the donor does not receive the service. Our service organizations include art and culture nonprofits, religious organizations, and nonprofits in the education or medical field. The remaining entities are classified as public charities (Kitching et al., 2012). Thus, the main distinction between these two nonprofit types is whether the donor is the service recipient (Balsam and Harris, 2014). As noted in Table 1, our final sample consists of 57,478 service organizations and 35,639 public charities. The service organizations consist of $53.7 \%$ of medical and $26.0 \%$ of educational nonprofits while public charities consist of $59.9 \%$ of human services and $24.8 \%$ of public and societal benefit nonprofits.

\subsection{Measure of Excess Spending}

Our proxy for nonprofit opportunistic spending is administrative expenses. We focus on this expense because it can signal that management is diverting resources away from the nonprofit's core mission and toward their own personal benefit. Consistent with this view, prior studies have found that donors consider administrative expenses when contributing to the nonprofit and that administrative expenses are negatively correlated with contributions (Tinkelman and Mankaney, 2007). Because total administrative expenses can be a function of several entity characteristics, we follow Yetman and Yetman (2012b) and compute excess administrative expenses using the following model: ${ }^{5}$

$$
\begin{aligned}
& \text { Admin }_{i, t}=\beta_{0}+\beta_{1} \text { Direct Donations }_{i, t}+\beta_{2} \text { Feeder Donations }_{i, t}+\beta_{3} \text { Govt Grants }_{i, t}+ \\
& \beta_{4} \text { Total Expenses }_{i, t}+\beta_{5} \text { Total Assets }_{i, t}+\beta_{6}\left(\text { Total Assets }^{2}{ }_{i, t}+\beta_{7} \text { Year FE }_{i, t}+\beta_{8}\right. \text { Industry } \\
& F E_{i, t}+\varepsilon_{i, t}
\end{aligned}
$$

We use Total Assets ${ }^{2}$ to control for the possibility of a non-linear association between size and administrative expenses. The model also includes year and time fixed effects. The

\footnotetext{
${ }^{5}$ All model variable definitions are included in Appendix A.
} 
residual from this regression represents the difference between the actual and predicted administrative expenses. If the residual is positive, then the nonprofit "overspent" on administrative expenses compared to what would be expected of that nonprofit. Thus, as later discussed for Model 2, we code Over Spend Admin equal to 1 if the nonprofit's residual is positive, and 0 otherwise.

\subsection{Measure of Trust}

Trust, our variable of interest, is computed based on survey data available from the World Values Survey. ${ }^{6}$ This survey, started in 1981, is conducted by a global network of social scientists with a stated purpose of helping scientists and policy makers understand changes in the beliefs, values, and motivations of people throughout the world (World Values Survey website, 2016). Data regarding trust are collected by the survey approximately every 6-8 years. Specifically, the survey asks respondents the following question: Generally speaking, would you say that most people can be trusted or that you need to be very careful in dealing with people?

The responses are organized by nine geographic regions in the United States. ${ }^{7}$ The Trust variable yields the percentage of people in different regions of the United States who consider themselves to be trusting. This trust variable is a commonly accepted basis for measuring generalized trust in the literature (e.g. Pevzner et al., 2015; Knechel et al., 2017). Prior literature suggests that there is relative stability of trust levels over extended periods of time (Knechel et al., 2017; Bjornskov, 2007). Accordingly, we use the latest survey applicable to our sample

\footnotetext{
${ }^{6}$ According to the World Values Survey (WVS) website the survey "seeks to use the most rigorous, high-quality research designs in each country. The WVS consists of nationally representative surveys conducted in almost 100 countries, containing almost 90 percent of the world's population, using a common questionnaire. The WVS is the largest non-commercial, cross-national, time series investigation of human beliefs and values ever executed. According to the WVS, it is the only academic study covering the full range of global variations, from very poor to very rich countries, in all of the world's major cultural zones."(http://www.worldvaluessurvey.org/wvs.jsp).

${ }^{7}$ Appendix B lists the states within each of the nine regions.
} 
(Wave 5), which covers the period 2005-2009. ${ }^{8,9}$ Consistent with the methodology of the World Values Survey, we provide trust data on the regional level.

\subsection{Empirical Design}

We estimate the regression model below to test our hypothesis, which examines the association between trust and opportunistic behavior.

Over Spend Admin int, $=\beta_{0}+\beta_{1}$ Trust $_{i, t}+\beta_{2}$ Donation Intensity $_{i, t}+\beta_{3}$ Donation Growth $_{i, t}+$ $\beta_{4}$ Total Assets $_{i, t-1}+\beta_{5}$ Total Rev $_{i, t-1}+\beta_{6}$ Small Size $_{i, t-1}+\beta_{7}$ Leverage $_{i, t}+\beta_{8}$ Prof Acct $_{i, t}+$ $\beta_{9}$ State Prosecution $_{i, t}+\beta_{10}$ Fin Need $_{i, t-1}+\beta_{11}$ GDP $_{i, t}+\beta_{12}$ GDP Growth ${ }_{i, t}+\beta_{13}$ Non Profit Density $_{i, t}+\beta_{14}$ Time Trend $_{i, t}+\varepsilon_{i, t}$

Over Spend Admin and Trust are as defined above. Our coefficient of interest is $\beta_{1}$. If Trust mitigates opportunistic spending, then $\beta_{1}$ would be negative; however, if Trust exacerbates such behavior, $\beta_{1}$ would be positive. Consistent with our hypothesis, we predict that $\beta_{1}$ will be positive and significant.

This study controls for several nonprofit organizational characteristics that prior literature finds to be associated with expense misreporting. Specifically, we include Donation Intensity to control for a nonprofit's reliance on donations and Donation Growth to control for the notion that high-growth entities are more likely to misreport administrative expenses (Yetman and Yetman, 2012b). We control for entity size by including Total Assets and Total Rev. To help control for differences associated with nonprofit size, we set Small Size equal to 1 if the nonprofit has total assets under one million dollars in the current year (Yetman and Yetman,

\footnotetext{
${ }^{8}$ The survey includes 1,249 U.S. respondents. The breakdown by region is as follows: New England: $6.4 \%$, MidAtlantic: 17.3\%, South Atlantic: 16.6\%, East South Central: 7.3\%, West South Central: 9.5\%, East North Central: 13.4\%, West North Central: 6.5\%, Rocky Mountain: 7.9\%, Pacific: 15.1\%.

${ }^{9}$ Wave 6 covers the period of time ending 2014, which is beyond our sample period.
} 
2013), and ' 0 ' otherwise. ${ }^{10}$ We include Leverage to control for the potential effects of creditor monitoring (Keating et al., 2008). Less financially stable nonprofits may misreport their administrative expenses to appear in better financial condition (Krishnan et al., 2006). Thus, to help control for the financial position of the nonprofit, we include Fin Need. We also control for the level of financial expertise. We determined whether nonprofits paid accounting expenses from information obtained from line 11c of the functional expense statement. Prof Acct is coded 1 if the nonprofit indicated it paid for external accounting services, and 0 otherwise.

Since our Trust variable is measured at the regional level, states within the same region are assigned the same Trust value. As such, we control for state-level differences. State Prosecution is an index developed in Desai and Yetman (2015) to capture the relative strength of a state's prosecution activity against nonprofits. We expect State Prosecution to be negatively associated with Over Spend Admin. We also control for GDP and GDP Growth of each state since trust can be correlated with economic factors (Bjornskov, 2007).

We also consider potential competition among nonprofits. Nonprofits that face a more competitive environment for donations could choose to spend their resources differently (Saxton et al., 2014). Thus, we include Non Profit Density, defined as the number of nonprofits within a given year and zip code. ${ }^{11}$ Time Trend is included to account for the changes in nonprofit reporting through time (Krishnan et al., 2006). Our model includes industry fixed effects, which is based on the single digit national taxonomy of exempt entities (NTEE), and standard errors calculated using the Huber-White robust method (White, 1982).

\section{Empirical Results}

${ }^{10}$ Our results are unchanged if we set Small Size equal to 1 if the nonprofit has under \$1 million in total revenue.

${ }^{11}$ Our results are similar if we define this variable at the state or regional level. 


\subsection{Summary Statistics}

Table 2, Panel A, displays descriptive statistics by each of the nine regions used for the trust data. As indicated, the national mean for Trust is 0.395 . Trust is reported highest in the Rocky Mountain region (0.439) and lowest in the East South Central region (0.231). The mean of Over Spend Admin is 0.522 , suggesting that over half the sample nonprofits are likely to spend more on administrative expenses than would be expected. The mean of Over Spend Admin is relatively even among the regions, with the highest mean in the South Atlantic region (0.539) and the lowest in the West North Central region (0.490). About 7\% of our sample is Small Size. Seventyfive percent of nonprofits report a Prof Acct, with Mid-Atlantic and Rocky Mountain nonprofits having the highest percentage (0.79) and East South Central nonprofits having the lowest percentage (0.70).

Panel B of Table 2 presents Pearson correlations of the main variables. Over Spend Admin has a positive correlation with Trust, providing some initial support for our hypothesis. As expected, nonprofit size and the presence of Prof Acct and State Prosecution are negatively associated with Over Spend Admin. In the next section, we test the association in the multivariate context by controlling for economic factors that could also impact administrative expenses.

\subsection{Main results}

Table 3 displays the results of Model (2). In column 1, which includes all observations, the coefficient on Trust is positive and significant at the $1 \%$ level $(\beta=0.54, z$-stat $=2.99)$. This supports $\mathrm{H} 1$ that nonprofits operating in higher-trust areas are more likely to overspend on administrative expenses and suggests that nonprofit managers are more opportunistic in the presence of high trust. 
While Trust is positively associated with Over Spend Admin on average, we next examine whether the effect is constant across entity types. In column 2, we present Model (2) only for the service organizations and note that Trust has a significantly positive coefficient ( $\beta=0.69, \mathrm{z}$-stat= 3.18). However, in column 3 , which presents only the results for public charities, Trust has a statistically insignificant coefficient ( $\mathrm{z}$-stat $=-0.45$ ). We also note that an F-test confirms that service organizations and public charities have significantly different Trust coefficients ( $\mathrm{p}=.047)$. Altogether, this evidence supports $\mathrm{H} 2$ and suggests that service organizations drive the overall association between Trust and Over Spend Admin. In other words, the service organizations that operate in high-trust areas are the nonprofits that are more likely to overspend on administrative expenses. ${ }^{12}$

Our result is consistent with Balsam and Harris (2014), who note that donors of service organizations are usually directly involved with the organization because they are also the service recipients and, thus, can directly observe the nonprofit's operations. As a result, these donors may rely on their observation, instead of financial information, for their monitoring. However, because observation may not be the most effective means of monitoring, managers of service organizations may be better able to opportunistically spend without raising objections from donors. Altogether, our findings suggest that not all nonprofits have the same principalagent relationship and that the nature of this relationship in service organizations makes overspending in the presence of high trust more likely.

We note that Total Assets and Total Rev have a negative coefficient in all three columns. This suggests that larger nonprofits are less likely to have excess administrative expenses. Additionally, the Small Size coefficient is negative in all three columns, consistent with the view

\footnotetext{
${ }^{12}$ In untabulated results, we drop observations that have affiliates reported on their Form 990 and note that the results of Table 3 are unchanged.
} 
that these relatively small entities (under $\$ 1$ million assets) may not have the excess resources to overspend. As expected, the negative Prof Acct coefficients for all three columns suggest that external accountants can mitigate overspending. In addition, State Prosecution is also negative in all three specifications, consistent with the view that nonprofits are less likely to overspend when there is a higher likelihood of being prosecuted for misdeeds. We also note that the Pseudo $\mathrm{R}^{2}$ for all observations in column 1 is $22 \%$ and the area under the ROC curve is 0.82 . In column 2 (3), for service organizations (public charities), the Pseudo $\mathrm{R}^{2}$ is $15 \%(40 \%)$ and the area under the ROC curve is $0.90(0.77)$.

In an unreported test, we examine the association of Trust on the likelihood of overspending on two specific types of administrative expense, travel and conferences, which could have a greater propensity for abuse. We sum up these two expense items and calculate the likelihood of overspending on these line items by using Model 1 to determine if there is a positive residual. This is the same procedure we used to calculate the main administrative overspending variable. We find that for service organizations, trust is positively associated with the likelihood of overspending on travel and conferences with a coefficient significant at the $1 \%$ level. This result provides additional support for our findings by demonstrating a type of expense that can be a target of overspending in response to high trust.

Overall, our findings in this section support our two hypotheses by revealing both that nonprofits operating in higher trust areas are more likely to overspend on administrative expenses and that this behavior is concentrated among service organizations. Accordingly, we report that, on average, trust is associated with opportunistic behavior in nonprofits, a result that contrasts overall with the for-profit literature. This is likely due to the relative lack of external enforcement in the nonprofit setting that is needed to accompany trust. Moreover, we show that 
nonprofit opportunistic behavior is most prevalent in the service organizations - a subset of nonprofits that may be subject to an especially low level of monitoring by donors.

\subsection{Cross Sectional Analysis}

Thus far, our evidence suggests that service organizations are the nonprofits where opportunistic behavior is most likely to occur. Although these organizations generally lack a high level of oversight from their donors, we perform additional testing to determine how other potential oversight mechanisms affect opportunism in the presence of higher trust. To that end, we examine the effect that external and internal monitoring conditions and information quality have on the association between Trust and Over Spend Admin in service organizations. ${ }^{13}$

The first mediating variable we examine is the competitive environment of the nonprofit. Nonprofits in competitive environments compete for donations (Saxton et al., 2014). Because administrative expenses are negatively correlated with donations (Tinkelman and Mankaney, 2007), it follows that nonprofits would try to be more efficient in highly competitive areas. Indeed, evidence from the for-profit literature suggests that competition acts as an external incentive to maximize efficiency (Giroud and Mueller, 2010). Thus, if competition is an appropriate external "disciplining" mechanism, it could deter managers from exploiting trust and causing donations to flow to a competing nonprofit. We measure competition using Non Profit Density.

The second area we examine is reporting quality. Significant changes were made to Form 990 in 2008, now requiring nonprofits to submit more detailed information pertaining to financial data and governance (Feng et al., 2014). Accordingly, in the latter years of our sample

\footnotetext{
${ }^{13}$ Our cross-sectional results are similar if we use the entire sample.
} 
(2008-2012), donors enjoy a richer information environment in which to analyze nonprofits (Yetman and Yetman, 2013). High information quality could signal to managers that donors can more thoroughly monitor them, thereby making managers less inclined to violate trust.

Next, we examine the external monitoring of nonprofits based upon three mechanisms. The first external mechanism is whether the nonprofit had an external financial audit and/or a federal single audit (A-133 audit). Second, we measure donor sophistication by whether the nonprofit has restricted donations. Sophisticated donors are more likely to attach restrictions to their donations, which in turn could limit the ability of the nonprofit to misappropriate funds (Yetman and Yetman, 2013). Third, we consider whether the nonprofit has issued a bond, since the terms of these bonds can act as a restraint on management (Yetman and Yetman, 2012b). We count how many external monitoring mechanisms exist for each nonprofit and then label that variable External Monitoring. Due to data availability, External Monitoring is available only between the years of 2008 and 2012. If trust needs to be accompanied by external monitoring (Robinson and Robinson, 2015), then the opportunistic behavior we document should vary by the level of external monitoring available.

The fourth cross-sectional variable we examine is the internal governance of the nonprofit. We consider five internal governance features as in Yetman and Yetman (2012b). First, we calculate the number of board members (board size) since a larger board may increase monitoring ability. We transform board size into a binary variable by splitting the sample at the median of board size and then labeling nonprofits above the median as Large Boards. Second, we consider the percentage of independent directors on a board, since ample literature suggests independent directors are more likely to be active monitors. Again, we split the sample at the 
median of the percentage of independent directors and then label nonprofits above the median as Highly Indep. Board.

The remaining internal governance features we examine are the inclusion of an audit committee, the performance of a formal board review of Form 990, and the outsourcing of management. An audit committee and board review suggests the board takes an active role in monitoring the entity, while outsourced management would likely be independent and less interested in opportunistic behavior. We calculate Governance by adding together the five binary governance variables. Again, we note that Governance is available only for years 2008 through 2012.

Accordingly, we have four cross-sectional variables of interest: local competition (measured by Non Profit Density), information quality (measured by the time period), External Monitoring and Governance. For all of these variables, except information quality, we split the sample at the median of the mitigating variable. We then run Model (2) twice, once each for the subsample above and below the median, to determine whether the positive association between Trust and Over Spend Admin is affected by these variables.

Table 4 displays the results of these tests. Our results reveal that Trust is positively associated with Over Spend Admin when there is weaker monitoring. Specifically, Trust has a positive and statistically significant coefficient in the subsamples with less competition, weaker internal governance, or weaker external monitoring. Moreover, we find that Trust has a positive and significant coefficient in the pre-2008 subsample, but has an insignificant coefficient in the 2008-2012 subsample. The overall insignificance of Trust in the post-2008 years suggests that, on average, increased information quality with the new Form 990 increased monitoring and, thus, reduced the likelihood of overspending. However, the external monitoring and governance 
tests are restricted to the 2008-2012 period, so even in the latter years of the sample, trust is associated with overspending in circumstances of weaker oversight.

Overall, the findings of this table suggest that service organizations are likely to overspend on administrative expenses in the presence of high trust when less monitoring exists and/or when there is lower information quality. Accordingly, we interpret this to mean that when there is less oversight and/or less quality information to enable oversight, service organizations are more likely to opportunistically spend in reaction to higher trust. ${ }^{14}$

\subsection{Alternative Measures}

Thus far, we have shown that Trust is positively associated with Over Spend Admin and presume that a positive residual from Model (1) suggests managerial opportunism through overspending. However, Yetman and Yetman (2012b) suggest that a positive residual can be a sign of "over-reporting" administrative expenses and an indication of expense inaccuracy. Therefore, in this section, we use alternative measures to examine the association of trust and varying dimensions of managerial opportunism.

If nonprofit managers are behaving opportunistically in the presence of high trust, it is reasonable to suggest that executives may receive abnormally high compensation. By using nonprofits' disclosures of total compensation of directors and officers obtained from line 5 of the functional expense statement, we compute industry-adjusted compensation as the nonprofit's compensation less the median compensation of the nonprofit's industry for the year and size decile. This approach follows that of Gaver and Im (2013). We code Over Spend Compensation

\footnotetext{
${ }^{14}$ We conduct an F-test to compare the Trust level in both subsamples of the mitigating variable. The F-test suggests that Trust is significantly different between high and low external monitoring $(\mathrm{p}<.0 .00)$, and between high and low governance ( $\mathrm{p}=.08)$. The F-test suggests Trust does not meaningfully vary between the competition subsamples $(\mathrm{p}=.91)$ or the partition based on years for the new Form $990(\mathrm{p}=.43)$.
} 
equal to 1 if adjusted compensation is positive and 0 otherwise. Thus, Over Spend Compensation captures the likelihood a nonprofit is paying its key employees more than do its industry and size peers in a given year. ${ }^{15}$

Second, we set Abnormal Accruals equal to 1 if the probability of program ratio manipulation is higher than the median value, and 0 otherwise (Yetman and Yetman, 2013). ${ }^{16}$ Accordingly, if managers are behaving opportunistically in the presence of higher trust, one likely outcome would be the manipulation of the program ratio-- defined as program expenses divided by total expenses. Third, we examine the likelihood to overspend on fundraising expenses. We follow Yetman and Yetman (2013) to model fundraising expenses. We code Over Spend FR equal to 1 if the residual from the expectation regression is positive, and 0 otherwise. ${ }^{17}$

We estimate Model (2) with each of these three alternate variables as the dependent variable. We run this analysis separately for service organizations and for public charities. Table 5 presents the results. For service organizations, Trust has a positive and significant coefficient across all three alternate variables. That is, service organizations are more likely to overpay their employees, manage their program ratio, and overspend on fundraising when they operate in a high trust region. In comparison, Trust has a significantly negative coefficient for public charities

\footnotetext{
${ }^{15}$ We acknowledge a limitation of this approach in that we cannot quantify the number of employees reported by each nonprofit under the compensation line item. Our results are unchanged if we use the compensation of the top five officers as the dependent variable.

${ }^{16}$ We calculate Abnormal Accruals following Trussel (2003) as 1/[1+e $(-\mathrm{Z})$, where Z equals: $-2.807-0.702 *$ Margin $1.360 *$ DefExp $+0.030 *$ Growth $+0.938 *$ DepProg-2.375*DefRev+1.326*ProgCh. Margin is (total revenues-total expenses)/total revenues. DefExp is (prepaid expenses + other assets)/total assets. Growth is percentage change in total revenues between year $t$ and $t-1$. DepProg is (depreciation)/(depreciation + total fixed assets). DefRev (deferred revenues/total assets). ProgCh is the percentage change in program ratio between year $\mathrm{t}$ and $\mathrm{t}-1 /$

${ }^{17}$ We use follow Yetman and Yetman (2013) and model fundraising expense as follows: Fundraising Expense $i_{i, t}=\beta_{0}$ $+\beta_{1}$ Direct Donations $_{i, t}+\beta_{2}$ Govt Grants $_{i, t}+\beta_{3}$ Indirect Donations $_{i, t}+\beta_{4}$ Total Assets $_{i, t}+\beta_{5}$ Total Rev $_{i, t}+\beta_{6}$ Age $_{i, t}+$ $\beta_{7}$ Leverage $_{i, t}+\beta_{8}$ Year $F E_{i, t}+\beta_{9}$ Industry $F E_{i, t}+\varepsilon_{i, t}$
} 
with respect to overspending on fundraising and excess pay, and a significantly positive coefficient for Abnormal Accruals.

Altogether, for public charities, the findings suggest that Trust may act as a deterrent against opportunistic behavior, but the evidence also indicates that Trust may be associated with misreporting in these entities. For service organizations, the results of these tests support our hypothesis that societal trust is positively associated with opportunistic behavior by nonprofit managers.

\subsection{Sensitivity Analysis}

We perform sensitivity analysis to test the robustness of our results. While our Trust variable is the commonly accepted basis for measuring generalized trust in the literature, it has one fixed value for each nonprofit throughout the entire sample. To help compensate for this, we create variation in the measurement of trust by calculating Industry Adjusted Trust, which is calculated as the difference, in a given year, between a nonprofit's trust value and the median trust value of the nonprofit's industry. Although Trust is constant for nonprofits and is measured at the regional level, the industry's median trust value would typically differ from that of an individual nonprofit because nonprofits in any industry tend to operate nationwide. In addition, the median value for industry trust could change year to year as nonprofits join or exit an industry. We re-estimate Model (2) using Industry Adjusted Trust as the independent variable only for the subset where Industry Adjusted Trust is not equal to zero. That is, we include only those observations where the nonprofit's trust value is different than its industry median. Thus, if Industry Adjusted Trust is positive (negative), it indicates that the nonprofit operates in a higher (lower) trust region than other nonprofits doing similar work. 
As displayed in Table 3, we estimate this regression for the pooled sample and then for service organizations and public charities individually. We note that in column 1 of Table 6 , Industry Adjusted Trust is significantly positive for all observations, consistent with our main findings. In column 2, Industry Adjusted Trust has a significantly positive coefficient for service organizations, but has a statistically insignificant coefficient for public charities. Thus, this test provides further support for our hypothesis that trust is positively associated with opportunistic behavior by nonprofit managers and it also provides further evidence that service organizations drive the relation.

Additionally, we employ a different classification of service organizations and public charities. In our main tests, we categorized nonprofits based on their mission. However, nonprofits in certain industries may be less sensitive to efficiency ratios or may naturally have a greater need for administrative costs. Therefore, as a robustness check, we recalculate our classification based on a nonprofit's actual performance. Following Balsam and Harris (2014), we compute the ratio of program revenue to total revenue for each nonprofit. Those entities whose ratio is above the sample median are labeled as service organizations and those entities whose ratio below the median are labeled public charities. We follow this convention since nonprofits that generate more of their total revenue from program revenue are more likely providing a service to donors, whereas public charities rely more on contributions. We reestimate Model (2) for these two subsamples. As indicated in column 4 of Table 6, we find that Trust has a positive and significant coefficient in the service organizations subsample but is insignificant in the public charities subsample. Overall, this supports our finding that trust is positively associated with opportunistic behavior by service organization managers and suggests our results are robust to an alternate classification of nonprofits. 
An implicit assumption in our industry classification between service organizations and public charities is that all nonprofits in a category behave similarly. As a further examination, we decompose the service organization category into its main industry classifications (arts, culture and humanities industry, medical, education, or religious organizations), and estimate Model (2) by each of these service industries. In untabulated results, we find that Trust is positively associated with the likelihood to overspend on administrative expenses for nonprofits in the education industry as well as for religious organizations, but has a statistically insignificant coefficient for the medical and art-related industries. ${ }^{18}$ When we perform a similar analysis by industry type for public charities, our untabulated results show Trust has a statistically insignificant coefficient for each public charity industry. Overall, these results provide evidence consistent with the results of our prior tests. Namely, we find support for $\mathrm{H} 1$ primarily in service organizations and, therefore, find evidence to support $\mathrm{H} 2$.

Moreover, in untabulated results, we also find our results are robust if we alter Over Spend Admin to equal 1 only if the nonprofit's positive residual is above the median of all positive residuals, and 0 otherwise.

\subsection{Limitations}

Our study is subject to limitations in connection with our trust data. The World Values Survey provides a useful dataset on trust levels in the U.S. However, the methodology of the survey yields data that precludes finer analysis. Specifically, the trust measure is based on large geographic regions, thus presuming that trust is similar within these regions. In addition, the survey is conducted periodically, so our trust measure is based on one survey and held constant

\footnotetext{
${ }^{18}$ We note that Trust does not impact Over Spend Admin when education and medical-related nonprofits are eliminated from the Service Organization subsample.
} 
throughout the sample period. Consistent with prior trust literature, we assume a relative stability in trust levels over time. ${ }^{19}$ As mentioned in Section 4.5 , we try to address these concerns by creating a transformed version of the trust variable that creates variation with respect to time and geographic region. However, to the extent that this test cannot fully control for the limitations of the trust variable, our results could be impacted by these underlying assumptions.

We also note two other caveats to our study related to our measurement of administrative overspending. We presume that the residual of excessive administrative expenses represents overspending. Although we find that trust is also associated with abnormal accruals in Table 6, an alternate interpretation of the main findings in Table 3 could be that trust is associated with "higher-quality" reporting. Second, a nonprofit's manager would presumably have a similar trust level as the region in which the firm operates. Although we assume nonprofit managers are not inhibited by their region's trust level, we acknowledge that trust could also preclude inappropriate behavior on a personal level.

\section{Conclusion}

Our paper explores the impact of generalized societal trust on opportunistic behavior of nonprofit organizations. Evidence from the for-profit literature suggests that the level of generalized trust enhances the credibility of financial information and is associated with lower levels of managerial opportunism (Pevzner et al., 2015). However, the significant differences that exist between the for-profit and nonprofit environments make it unclear whether trust plays a similar role for nonprofits. We hypothesize that, given the relative lack of external monitoring and enforcement of nonprofits, trust is associated with greater opportunism on the part of

\footnotetext{
${ }^{19}$ We confirm that our main results are unchanged when trust survey data from other time periods are included. However, even with the addition of those surveys, we must assume that trust is stable over the multi-year period for which each survey covers.
} 
nonprofit managers. Consistent with this view, we find a positive relation between trust and overspending on administrative expenses, driven primarily by the behavior of service organization nonprofits as opposed to public charities. While our results point to a difference between these two nonprofit types, we also find differences among service organizations. Specifically, we find that the trust-overspending association for service organizations is present only for education and religious organizations. Additional tests reveal that trust has a similar impact on excess compensation and abnormal accruals in service organizations. We further show that such overspending in the presence of trust is most prevalent when there is weaker overall oversight.

Overall, our results support the notion and anecdotal evidence that, absent effective enforcement mechanisms, trust can be exploited (Robinson and Robinson, 2015; Knechel et al., 2017). While our study focuses on the role of trust in the nonprofit environment, our results help inform the much broader discussion of the role that trust plays in economic behavior and how its potential benefits can be realized. In addition to potentially assisting nonprofit donors make better-informed decisions, our findings can help federal and state organizations implement laws and regulations designed to improve financial reporting in the nonprofit sector. 


\section{References:}

Aghion, P., Algan, Y., Cahuc, P., Shleifer, A., 2010. Regulation and distrust. Quarterly Journal of Economics 125, 1015-1049.

Ahern, K.R., Daminelli, D., Fracassi, C., 2015. Lost in translation? The effect of cultural values on mergers around the world. Journal of Financial Economics, 117(1), 165-189.

Andreoni, J., 1990. Impure Altruism and Donations to Public Goods: A Theory of Warm-Glow Giving. The Economic Journal 100-401.

Archambeault,D. S., Webber, S., and Greenlee, J., 2015. Fraud and Corruption in U.S. Nonprofit Entities: A Summary of Press Reports. 2008-2011. Nonprofit and Voluntary Sector Quarterly, 44(6), 1194-1224,

Atuahene-Gima, K., \& Li, H., 2002. When does trust matter? Antecedents and contingent effects of supervisee trust on performance in selling new products in China and the United States. Journal of Marketing, 66(3), 61-81.

Baber, W. R., Daniel, P. L., Roberts, A. A., 2002. Compensation to managers of charitable organizations: An empirical study of the role of accounting measures of program activities. The Accounting Review, 77(3), 679-693.

Balsam, S. Harris, E., 2014 The Impact of CEO Compensation on Nonprofit Donations. The Accounting Review 89(2), 425-450.

Becker, G., 1974. A Theory of Social Interaction. Journal of Political Economy 82-2. 10631093.

Bjørnskov, C., 2007. Determinants of generalized trust: A cross-country comparison. Public Choice 130 (1-2), 1-21.

Blodgett, M. S., Melconian, L., 2012. Healthcare Nonprofits: Enhancing Governance and Public Trust. Business and Society Review, 117(2), 197-219.

Desai, M.A. and Yetman, R.J., 2015. Constraining managers without owners: Governance of the not-for-profit enterprise. Journal of Government \& Nonprofit Accounting, 4(1), 53-72.

Dong, W., Han, H., Ke, Y., Chan, K. C., 2016. Social Trust and Corporate Misconduct: Evidence from China. Journal of Business Ethics, 1-24.

Fama, E., Jensen, M., 1983a. Separation of Ownership and Control. Journal of Law and Economics, 26 (2), 301-325. Fama, E., Jensen,M., 1983b. Agency Problems and Residual Claims. Journal of Law and Economics, 26 (2), 327-349. 
Feng, N.C., Ling, Q., Neely, D. and Roberts, A.A., 2014. Using archival data sources to conduct nonprofit accounting research. Journal of Public Budgeting, Accounting \& Financial Management, 26(3), 458-493.

Garbarino, E., Johnson, M. S., 1999. The different roles of satisfaction, trust, and commitment in customer relationships. The Journal of Marketing, 63 (2): 70-87.

Gaver, J.J. and Im, S.M., 2013. Funding sources and excess CEO compensation in not-for-profit organizations. Accounting Horizons, 28(1), pp.1-16.

Giroud, X., Mueller, H.M., 2010. Does corporate governance matter in competitive industries?. Journal of Financial Economics, 95(3), pp.312-331.

Gordon, T.P and Khumawala, S.P., 1999. The demand for non-profit financial statements: A model of individual giving. Journal of Accounting Literature Vol. 18: 31-56.

Grunewald, D., 2008. The Sarbanes-Oxley Act will change the governance of nonprofit organizations. Journal of Business Ethics, 80(3): 399-401.

Hansmann, H.B., 1980. The role of nonprofit enterprise. The Yale Law Journal, 89(5), 835901.

Hilary, G. and Huang, S., 2015. Trust and Contracting. Working Paper. Available at SRRN: https://ssrn.com/abstract=2604974 or http://dx.doi.org/10.2139/ssrn.2604974

Keating, E.K., Parsons, L.M., Roberts, A.A., 2008. Misreporting fundraising: How do nonprofit organizations account for telemarketing campaigns? The Accounting Review, 83(2), 417-446.

Kitching, K.A., A.A. Roberts, Smith, P.C., 2012. Nonprofit resource allocation decisions: A study of marginal versus average spending. Journal of Governmental \& Nonprofit Accounting, 1(1), 1-19.

Knack, S., Keefer, P., 1997. Does social capital have an economy payoff? A cross-county investigation. Quarterly Journal of Economics 112 (4): 1251-1288.

Knechel, W. R., Mintchik, N., Pevzner, M., Velury, U. 2017. The Effects of Generalized Trust and Civic Cooperation on the Big N Presence and Audit Fees Across the Globe. Working Paper. Available at SSRN: http://ssrn.com/abstract=2815180

Krishnan, R., Yetman, M., Yetman, R., 2006. Expense misreporting in nonprofit organizations. The Accounting Review 81 (2): 399-420.

Lloyd, R., De las Casas, L., 2006. NGO self-regulation: enforcing and balancing accountability. One World Trust. Available at: www. oneworldtrust. org. 
Morgan, R., Hunt, S., 1994. The commitment-trust theory of relationship marketing. The Journal of Marketing, 58 (3):20-38.

Nanda, D., Wysocki, P., 2013. Trust, external capital, and financial transparency. Working paper.

Neely, D., 2011. The impact of regulation on the U.S. nonprofit sector: Initial evidence from the Nonprofit Integrity Act of 2004. Accounting Horizons, 25(1), 107-125.

Pevzner, M., Xie, F., Xin, X., 2015. When firms talk, do investors listen? The role of trust in stock market reactions to corporate earnings announcements. Journal of Financial Economics 117(1), 190-223.

Robinson, P., Robinson, S., 2015. Pirates, Prisoners, and Lepers: Lessons from Life Outside the Law. Potomac Books.

Saxton, G., Neely, D., Guo, C., 2014. Web disclosure and the market for charitable contributions." Journal of Accounting and Public Policy 33(2): 127-144.

Tinkelman, D., Mankaney, K., 2007. When is administrative efficiency associated with charitable donations?. Nonprofit and Voluntary Sector Quarterly, 36(1), 41-64.

Trussel, J., Parsons, L., 2007. Financial reporting factors affecting donations to charitable organizations. Advances in Accounting, 23: 263-285.

Yetman, M.H., Yetman, R.J., 2012a. How Does the Incentive Effect of the Charitable Deduction Vary across Charities? The Accounting Review, 88(3), pp.1069-1094.

Yetman, M.H., Yetman, R.J., 2012b. The effects of governance on the accuracy of charitable expenses reported by nonprofit organizations. Contemporary Accounting Research, 29(3), pp.738-767.

Yetman, M., Yetman, R., 2013. Do donors discount low-quality accounting information? The Accounting Review, 88(3), 1041-1067.

Wei, C., Zhang, L., 2015. Trust and Certification in Financial Markets: Evidence from Reactions to Earnings News. Working Paper. Available at SSRN: https://ssrn.com/abstract $=2469034$

White, H. (1982), Maximum likelihood estimation of misspecified models, Econometrica 50, $1-25$.

World Values Survey website, 2016. Available at: http://www.worldvaluessurvey.org/wvs.jsp

Zak, P., Knack, S., 2001. Trust and growth. The Economic Journal 111 (470): 295-32 


\begin{tabular}{|c|c|}
\hline \multicolumn{2}{|r|}{ Appendix A: Definitions } \\
\hline Variable Name & Definition \\
\hline $\begin{array}{l}\text { Abnormal } \\
\text { Accruals }\end{array}$ & $\begin{array}{l}\text { Set to } 1 \text { if the probability of program ratio manipulation is higher than the median value, and } \\
0 \text { otherwise. Program ratio manipulation is given in Footnote } 8 \text {. }\end{array}$ \\
\hline Admin & $\begin{array}{l}\text { The nonprofit's total administrative expenses; total management and general expenses from } \\
\text { the functional expense section of Form } 990 \text {. }\end{array}$ \\
\hline Competition & The number of other nonprofits in the zip code of a given nonprofit in year $t$. \\
\hline Direct Donations & The natural log of total donations given to the nonprofit from individuals or other entities \\
\hline $\begin{array}{l}\text { Donation } \\
\text { Growth, }\end{array}$ & The percent change in Direct Donations from year t-1 to year t. \\
\hline $\begin{array}{l}\text { Donation } \\
\text { Intensity }\end{array}$ & The ratio of Direct Donations to total revenue \\
\hline $\begin{array}{l}\text { Over Spend } \\
\text { Compensation }\end{array}$ & $\begin{array}{l}\text { Equal to } 1 \text { if adjusted compensation is positive, and } 0 \text { otherwise. Adjusted Compensation is } \\
\text { nonprofit compensation less the industry median in a given year. }\end{array}$ \\
\hline $\begin{array}{l}\text { External } \\
\text { Monitoring }\end{array}$ & $\begin{array}{l}\text { An index that gives one point for the presence of the following: restricted donations, financial } \\
\text { audit, A-133 audit, bond. }\end{array}$ \\
\hline $\begin{array}{l}\text { Feeder } \\
\text { Donations }\end{array}$ & Total donations from federated fundraising organizations \\
\hline Fin Need & Total net assets divided by total assets \\
\hline GDP & Year gross domestic product of state where the nonprofit operates. \\
\hline GDP Growth & Percentage change in GDP from year $\mathrm{t}-1$ to year $\mathrm{t}$.. \\
\hline Governance & $\begin{array}{l}\text { An index that gives one point for presence of the following: audit committee, review of Form } \\
990 \text { by the board, delegated management, board size above the sample median, percentage of } \\
\text { outsiders above sample median. }\end{array}$ \\
\hline Govt Grants & Total grants from federal, state, or local agencies. \\
\hline $\begin{array}{l}\text { Highly Indep. } \\
\text { Board. }\end{array}$ & $\begin{array}{l}\text { Coded } 1 \text { if nonprofit is above sample median of percentage of independent directors, and } \\
\text { coded } 0 \text { otherwise. }\end{array}$ \\
\hline $\begin{array}{l}\text { Industry } \\
\text { Adjusted Trust }\end{array}$ & $\begin{array}{l}\text { The difference between a nonprofit's trust value and the median trust value of the nonprofit's } \\
\text { industry in a given year. }\end{array}$ \\
\hline $\begin{array}{l}\text { Information } \\
\text { Quality }\end{array}$ & Coded 1 if the year is between $2008-2012$ and 0 if the year is prior to 2008. \\
\hline Large Boards & Coded 1 if the nonprofit is above the sample median of board size, and coded 0 otherwise. \\
\hline Leverage & Total liabilities divided by total assets. \\
\hline $\begin{array}{l}\text { Non Profit } \\
\text { Density }\end{array}$ & The number of nonprofits in the zip code where the nonprofit operates $\mathrm{p}$ er year. \\
\hline $\begin{array}{l}\text { Over Spend } \\
\text { Admin }\end{array}$ & Coded 1 if residual from Model (1) is positive and 0 otherwise. \\
\hline Over Spend FR & Coded 1 if the residual from the expectation regression is positive and 0 otherwise \\
\hline Prof Acct & Coded 1 if the nonprofit spent money for outside professional accountant and 0 otherwise. \\
\hline Public Charities & Coded 1 if the nonprofit is not a service organization and 0 otherwise. \\
\hline $\begin{array}{l}\text { Service } \\
\text { Organizations }\end{array}$ & $\begin{array}{l}\text { Coded } 1 \text { if a nonprofit is in the following industries: arts, culture and humanities, health, } \\
\text { education, and religious organizations; coded } 0 \text { otherwise. }\end{array}$ \\
\hline Small Size & $\begin{array}{l}\text { Coded } 1 \text { if the nonprofit has total assets under one million dollars in the current year and } 0 \\
\text { otherwise. }\end{array}$ \\
\hline $\begin{array}{l}\text { State } \\
\text { Prosecution }\end{array}$ & $\begin{array}{l}\text { An index developed in Desai and Yetman (2015) to capture the relative strength of a state's } \\
\text { prosecution activity against nonprofits. }\end{array}$ \\
\hline Total Assets & The natural $\log$ of prior year total assets \\
\hline Total Expenses & Total nonprofit expenses \\
\hline Total Rev & The natural of prior year total revenue. \\
\hline
\end{tabular}




\begin{tabular}{|l|l|}
\hline Trust & $\begin{array}{l}\text { A measure of the trust in a region. The variable is based on a questionnaire administered by } \\
\text { the World Values Survey and yields the percentage of people in different regions of the } \\
\text { United States who consider themselves trusting. }\end{array}$ \\
\hline
\end{tabular}

\section{Appendix B:}

\section{States in Trust Regions}

East North Central: Illinois, Indiana, Michigan, Ohio, Wisconsin

East South Central: Kentucky, Tennessee, Alabama, Mississippi

Mid-Atlantic: New Jersey, New York, Pennsylvania

New England: Connecticut, Maine, Massachusetts, New Hampshire, Rhode Island, Vermont

Rocky Mountain: Montana, Idaho, Wyoming, Colorado, New Mexico, Arizona, Utah, Nevada

South Atlantic: Delaware, Maryland, Washington, D.C., Virginia, West Virginia, North Carolina, South Carolina, Georgia, Florida

West North Central: Minnesota, Iowa, Missouri, North Dakota, South Dakota, Nebraska, Kansas

West South Central: Arkansas, Louisiana, Oklahoma, Texas

Pacific: Washington, Oregon, California, Alaska, Hawaii 
Table 1: Sample Selection

1986-2012 SOI nonprofit observations

Less: Observations with total expense, total revenue, total administrative expense, total fundraising expense, total program expense, total assets, or total compensation is under $\$ 1,000$

Less: Observations where fundraising, administrative and program expenses

expenses do not equal total expenses

Less: Observations missing computed variables

93,117

\section{Service Organizations}

Arts, Culture and Humanities

Education

Medical

Religious Organizations

Total Service Organizations

\begin{tabular}{rr} 
Observations & $\boldsymbol{\%}$ \\
\hline 10,053 & 17.5 \\
14,972 & 26.0 \\
30,841 & 53.7 \\
1,612 & 2.8 \\
\hline $\mathbf{5 7 , 4 7 8}$ & $\mathbf{1 0 0}$
\end{tabular}

Public Charities

\begin{tabular}{rr} 
Observations & \% \\
\hline 3,639 & 10.2 \\
21,332 & 59.9 \\
1,824 & 5.1 \\
8,844 & 24.8 \\
\hline $\mathbf{3 5 , 6 3 9}$ & $\mathbf{1 0 0}$
\end{tabular}


Table 2: Descriptive Statistics

Panel A: Univariate Statistics by Region

\begin{tabular}{|c|c|c|c|c|c|c|c|c|c|c|c|c|c|c|}
\hline Region & Trust & $\begin{array}{c}\text { Over } \\
\text { Spend } \\
\text { Admin }\end{array}$ & $\begin{array}{l}\text { Donation } \\
\text { Intensity }\end{array}$ & $\begin{array}{c}\text { Donation } \\
\text { Growth }\end{array}$ & Assets & $\begin{array}{l}\text { Total } \\
\text { Rev }\end{array}$ & $\begin{array}{c}\text { Small } \\
\text { Size }\end{array}$ & Leverage & $\begin{array}{l}\text { Prof } \\
\text { Acct }\end{array}$ & $\begin{array}{l}\text { State } \\
\text { Pros }\end{array}$ & $\begin{array}{c}\text { Fin } \\
\text { Need }\end{array}$ & GDP & $\begin{array}{c}\text { GDP } \\
\text { Growth }\end{array}$ & $\begin{array}{c}\text { NP } \\
\text { Density }\end{array}$ \\
\hline All $\mathrm{Ob}$ & 0.395 & 0.522 & 0.269 & 1.421 & 16.834 & 16.000 & 0.068 & 0.274 & 0.748 & 4.692 & 0.657 & 12.622 & 0.046 & 2.728 \\
\hline $\begin{array}{l}\text { East North } \\
\text { Central }\end{array}$ & 0.389 & 0.509 & 0.248 & 1.301 & 16.931 & 16.070 & 0.061 & 0.277 & 0.768 & 0.721 & 0.721 & 12.691 & 0.039 & 2.464 \\
\hline $\begin{array}{l}\text { East South } \\
\text { Central }\end{array}$ & 0.231 & 0.526 & 0.301 & 0.987 & 16.682 & 15.788 & 0.065 & 0.238 & 0.699 & 4.636 & 0.763 & 11.834 & 0.044 & 1.669 \\
\hline Mid-Atlantic & 0.389 & 0.506 & 0.248 & 0.986 & 16.983 & 16.206 & 0.062 & 0.295 & 0.792 & 5.000 & 0.377 & 13.274 & 0.043 & 4.276 \\
\hline New England & 0.425 & 0.510 & 0.210 & 1.427 & 17.040 & 16.171 & 0.048 & 0.275 & 0.786 & 4.334 & 0.728 & 11.851 & 0.043 & 2.799 \\
\hline Rocky Mountain & 0.439 & 0.506 & 0.248 & 0.986 & 16.983 & 16.206 & 0.062 & 0.295 & 0.792 & 5.000 & 0.377 & 13.274 & 0.043 & 4.491 \\
\hline South A & 0.385 & 0.539 & 0.297 & 2.580 & 16.814 & 15.931 & 0.063 & 0.268 & 0.729 & 4.228 & 0.733 & 12.329 & 0.049 & 2.794 \\
\hline $\begin{array}{l}\text { West No } \\
\text { Central }\end{array}$ & 407 & 0.490 & 0.270 & 1.469 & 16.794 & 15.957 & 0.073 & 0.257 & 0.725 & 4.410 & 0.744 & 11.690 & 0.047 & 1.949 \\
\hline $\begin{array}{l}\text { West South } \\
\text { Central }\end{array}$ & 381 & 0.524 & 0.510 & 1.116 & 16.752 & 15.846 & 0.082 & 0.223 & 0.710 & 4.557 & 0.745 & 12.945 & 0.055 & 1.656 \\
\hline Pacific & 0.389 & 0.509 & 0.248 & 1.301 & 16.931 & 16.070 & 0.061 & 0.270 & 0.768 & 4.727 & 0.721 & 12.697 & 0.039 & 2.464 \\
\hline
\end{tabular}


Panel B: Correlations

\begin{tabular}{|c|c|c|c|c|c|c|c|c|c|}
\hline & Trust & $\begin{array}{l}\text { Over Spend } \\
\text { Admin }\end{array}$ & $\begin{array}{l}\text { Donation } \\
\text { Intensity }\end{array}$ & Assets & Leverage & Prof Acct & $\begin{array}{l}\text { State } \\
\text { Pros. }\end{array}$ & Fin Needs & GDP \\
\hline Over Spend Admin & $0.008 * * *$ & & & & & & & & \\
\hline Donation Intensity & $-0.017 * * *$ & $-0.071 * * *$ & & & & & & & \\
\hline Assets & $-0.007 * *$ & $-0.129 * * *$ & $-0.167 * * *$ & & & & & & \\
\hline Leverage & $0.032 * * *$ & $0.007 * *$ & $-0.179 * * *$ & $0.058 * * *$ & & & & & \\
\hline Prof Acct & $0.009 * * *$ & $-0.019 * * *$ & $-0.070 * * *$ & $0.117 * * *$ & $0.028 * * *$ & & & & \\
\hline State Pros. & $0.094 * * *$ & $-0.009 * * *$ & -0.004 & $0.008 * *$ & $0.035 * * *$ & $0.010 * * *$ & & & \\
\hline Fin Needs & 0.000 & -0.003 & 0.004 & $0.016 * * *$ & $-0.023 * * *$ & -0.002 & -0.001 & & \\
\hline GDP & $0.103 * * *$ & $0.180 * * *$ & $-0.046 * * *$ & $0.061 * * *$ & $0.045 * * *$ & $0.035 * * *$ & $0.651 * * *$ & -0.005 & \\
\hline Non Profit Density & 0.002 & $-0.041 * * *$ & $0.021 * * *$ & $0.056 * * *$ & $-0.007 * * *$ & $0.020 * * *$ & $0.035 * * *$ & 0.005 & $-0.01 * * *$ \\
\hline
\end{tabular}

This table provides descriptive statistics. Panel A displays univariate statistics and Panel B provides correlations of selected variables. All variables defined in the Appendix 
Table 3: Effect of Trust on Admin Expenses

Dependent Variable: Over Spend Admin

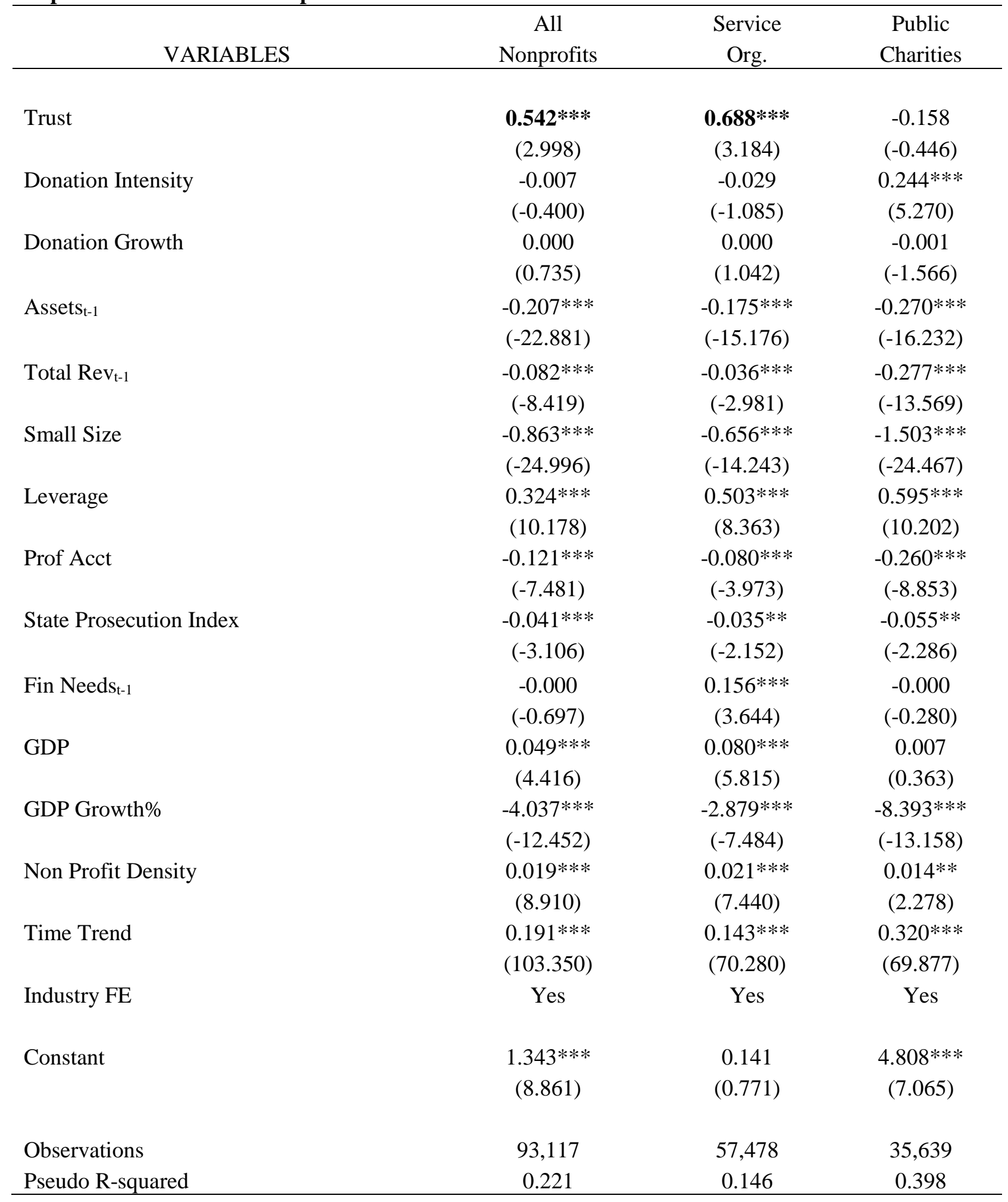


This table presents the results of Model (2). The dependent is Over Spend Admin. Trust is based on a questionnaire administered by the World Values Survey for the period 2005-2009. All other variables are defined in Appendix A. Industry fixed effects (NTEE) are included and robust standard errors are calculated. ****,*** represent significance at the $10 \%, 5 \%$ and $1 \%$ level, respectively. 
Table 4: Cross Section Tests -Service Organizations

Dependent Variable: Over Spend Admin

\begin{tabular}{|c|c|c|c|c|c|c|c|c|}
\hline \multirow[b]{2}{*}{ VARIABLES } & \multicolumn{2}{|c|}{ Local Competition } & \multicolumn{2}{|c|}{ Years } & \multicolumn{2}{|c|}{ Ext. Monitoring } & \multicolumn{2}{|c|}{ Governance } \\
\hline & $\begin{array}{c}\text { Below } \\
\text { Median }\end{array}$ & $\begin{array}{l}\text { Above } \\
\text { Median }\end{array}$ & $\begin{array}{l}\text { After } \\
2008\end{array}$ & $\begin{array}{c}\text { Before } \\
2008\end{array}$ & $\begin{array}{c}\text { Below } \\
\text { Median }\end{array}$ & $\begin{array}{l}\text { Above } \\
\text { Median }\end{array}$ & $\begin{array}{c}\text { Below } \\
\text { Median }\end{array}$ & $\begin{array}{l}\text { Above } \\
\text { Median }\end{array}$ \\
\hline Trust & $\begin{array}{c}\mathbf{0 . 8 7 4} * * * \\
(3.388)\end{array}$ & $\begin{array}{c}0.345 \\
(0.847)\end{array}$ & $\begin{array}{c}0.353 \\
(0.461)\end{array}$ & $\begin{array}{c}\mathbf{0 . 9 8 4} * * * \\
(4.149)\end{array}$ & $\begin{array}{c}\mathbf{5 . 4 9 6}^{* * * *} \\
(2.904)\end{array}$ & $\begin{array}{c}0.559 \\
(0.507)\end{array}$ & $\begin{array}{c}\text { 3.313** } \\
(2.573)\end{array}$ & $\begin{array}{c}0.161 \\
(0.126)\end{array}$ \\
\hline $\begin{array}{l}\text { Controls } \\
\text { Included } \\
\text { Industry FE }\end{array}$ & $\begin{array}{l}\text { Yes } \\
\text { Yes }\end{array}$ & $\begin{array}{l}\text { Yes } \\
\text { Yes }\end{array}$ & $\begin{array}{l}\text { Yes } \\
\text { Yes }\end{array}$ & $\begin{array}{l}\text { Yes } \\
\text { Yes }\end{array}$ & $\begin{array}{l}\text { Yes } \\
\text { Yes }\end{array}$ & $\begin{array}{l}\text { Yes } \\
\text { Yes }\end{array}$ & $\begin{array}{l}\text { Yes } \\
\text { Yes }\end{array}$ & $\begin{array}{l}\text { Yes } \\
\text { Yes }\end{array}$ \\
\hline Constant & $\begin{array}{c}-0.456 * * \\
(-1.963)\end{array}$ & $\begin{array}{c}1.536 * * * \\
(5.012)\end{array}$ & $\begin{array}{c}25.523 * * * \\
(14.882)\end{array}$ & $\begin{array}{c}-1.849 * * * \\
(-9.049)\end{array}$ & $\begin{array}{c}47.651 * * * \\
(8.873)\end{array}$ & $\begin{array}{c}14.579 * * * \\
(6.827)\end{array}$ & $\begin{array}{c}16.148 * * * \\
(7.222)\end{array}$ & $\begin{array}{c}28.996 * * * \\
(8.746)\end{array}$ \\
\hline $\begin{array}{l}\text { Observations } \\
\text { Pseudo R- } \\
\text { squared }\end{array}$ & 35,912 & 21,566 & 8,029 & 49,449 & 2,785 & 2,471 & 2,857 & 2,378 \\
\hline
\end{tabular}

This table presents the cross sectional results of Model (2). The sample is split at the median of each cross sectional variable and the model is run twice, once for the sample above and below the median. The dependent is Over Spend Admin. Trust is based on a questionnaire administered by the World Values Survey for the period 2005-2009. All other variables are defined in Appendix A. Industry fixed effects (NTEE) are included and robust standard errors are calculated.

$*, * *, * * *$ represent significance at the $10 \%, 5 \%$ and $1 \%$ level, respectively. 
Table 5: Effect of Trust on Alternate Variables

\begin{tabular}{|c|c|c|c|c|c|c|}
\hline \multirow[b]{2}{*}{ VARIABLES } & \multicolumn{3}{|c|}{ Service Organizations } & \multicolumn{3}{|c|}{ Public Charities } \\
\hline & $\begin{array}{c}\text { Over Spend } \\
\text { FR } \\
\end{array}$ & $\begin{array}{c}\text { Abnormal } \\
\text { Accruals }\end{array}$ & $\begin{array}{c}\text { Over Spend } \\
\text { Compensation }\end{array}$ & $\begin{array}{c}\text { Over Spend } \\
\text { FR } \\
\end{array}$ & $\begin{array}{c}\text { Abnormal } \\
\text { Accruals }\end{array}$ & $\begin{array}{c}\text { Over Spend } \\
\text { Compensation }\end{array}$ \\
\hline Trust & $\begin{array}{l}4.609 * * * \\
(15.967)\end{array}$ & $\begin{array}{c}\mathbf{1 . 0 3 5} * * * \\
(2.672)\end{array}$ & $\begin{array}{c}\mathbf{0 . 6 6 6}^{* * * *} \\
(2.741)\end{array}$ & $\begin{array}{c}-1.387 * * * \\
(-4.653)\end{array}$ & $\begin{array}{l}\mathbf{1 . 0 5 0} * * \\
(2.373)\end{array}$ & $\begin{array}{c}-1.264 * * * \\
(-3.657)\end{array}$ \\
\hline Industry FE & Yes & Yes & Yes & Yes & Yes & Yes \\
\hline $\begin{array}{l}\text { Controls Included } \\
\text { Constant }\end{array}$ & $\begin{array}{c}\text { Yes } \\
-12.034 * * * \\
(-45.186)\end{array}$ & $\begin{array}{c}\text { Yes } \\
6.127 * * * \\
(18.791)\end{array}$ & $\begin{array}{c}\text { Yes } \\
-5.307 * * * \\
(-26.417)\end{array}$ & $\begin{array}{c}\text { Yes } \\
-1.740^{* *} \\
(-2.241)\end{array}$ & $\begin{array}{c}\text { Yes } \\
4.589 * * * \\
(6.601)\end{array}$ & $\begin{array}{c}\text { Yes } \\
-14.099 * * * \\
(-19.656)\end{array}$ \\
\hline $\begin{array}{l}\text { Observations } \\
\text { Pseudo R-squared }\end{array}$ & $\begin{array}{c}57,408 \\
0.109\end{array}$ & $\begin{array}{c}57,428 \\
0.193\end{array}$ & $\begin{array}{c}57,478 \\
0.100\end{array}$ & $\begin{array}{c}35,639 \\
0.105\end{array}$ & $\begin{array}{c}35,639 \\
0.179\end{array}$ & $\begin{array}{c}35,639 \\
0.081\end{array}$ \\
\hline
\end{tabular}


Table 6: Sensitivity

Dependent Variable: Over Spend Admin

\begin{tabular}{|c|c|c|c|c|c|}
\hline VARIABLES & $\begin{array}{l}\text { All } \\
\text { Observations }\end{array}$ & $\begin{array}{l}\text { Service } \\
\text { Organization }\end{array}$ & $\begin{array}{l}\text { Public } \\
\text { Charities }\end{array}$ & $\begin{array}{l}\text { Service Org } \\
\text { (Alternate) }\end{array}$ & $\begin{array}{l}\text { Public Charities } \\
\text { (Alternate) }\end{array}$ \\
\hline Ind Adjusted Trust & $\begin{array}{c}\mathbf{0 . 5 1 6} * * * \\
(2.817)\end{array}$ & $\begin{array}{c}\mathbf{0 . 7 5 1} * * * \\
(3.425)\end{array}$ & $\begin{array}{c}-0.343 \\
(-0.956)\end{array}$ & & \\
\hline Trust & & & & $\begin{array}{c}0.738 * * * \\
(3.059)\end{array}$ & $\begin{array}{c}0.396 \\
(1.317)\end{array}$ \\
\hline Donation Intensity & $\begin{array}{l}-0.038 * \\
(-1.875)\end{array}$ & $\begin{array}{l}-0.073 * * \\
(-2.440)\end{array}$ & $\begin{array}{c}0.234 * * * \\
(4.261)\end{array}$ & -0.033 & $0.426 * * *$ \\
\hline Donation Growth & $\begin{array}{c}0.000 * * \\
(1.963)\end{array}$ & $\begin{array}{c}0.000 * * \\
(2.042)\end{array}$ & $\begin{array}{c}-0.000 \\
(-0.624)\end{array}$ & $\begin{array}{c}(-0.732) \\
0.000\end{array}$ & $\begin{array}{c}(10.021) \\
-0.000\end{array}$ \\
\hline Assets $_{\mathrm{t}-1}$ & $\begin{array}{l}-0.156^{* * * *} \\
(-16.226)\end{array}$ & $\begin{array}{c}-0.125 * * * \\
(-10.319)\end{array}$ & $\begin{array}{c}-0.209 * * * \\
(-11.653)\end{array}$ & $\begin{array}{c}(1.031) \\
-0.126^{* * *}\end{array}$ & $\begin{array}{c}(-0.390) \\
-0.210 * * *\end{array}$ \\
\hline Total $\operatorname{Rev}_{\mathrm{t}-1}$ & $\begin{array}{l}-0.155^{* * * *} \\
(-14.846)\end{array}$ & $\begin{array}{c}-0.107 * * * \\
(-8.516)\end{array}$ & $\begin{array}{c}-0.374 * * * \\
(-16.679)\end{array}$ & $\begin{array}{c}(-9.244) \\
-0.006\end{array}$ & $\begin{array}{c}(-15.310) \\
-0.386 * * *\end{array}$ \\
\hline Small Size & $\begin{array}{l}-0.839 * * * \\
(-21.789)\end{array}$ & $\begin{array}{l}-0.630 * * * \\
(-12.370)\end{array}$ & $\begin{array}{l}-1.510 * * * \\
(-21.632)\end{array}$ & $\begin{array}{c}(-0.407) \\
-0.476 * * *\end{array}$ & $\begin{array}{c}(-22.478) \\
-1.485 * * *\end{array}$ \\
\hline Leverage & $\begin{array}{c}0.447 * * * \\
(9.078)\end{array}$ & $\begin{array}{c}0.561 * * * \\
(9.006)\end{array}$ & $\begin{array}{c}0.618 * * * \\
(9.171)\end{array}$ & $\begin{array}{c}(-8.333) \\
0.399 * * *\end{array}$ & $\begin{array}{l}(-27.014) \\
0.643 * * *\end{array}$ \\
\hline Prof Acct & $\begin{array}{c}-0.130 * * * \\
(-7.336)\end{array}$ & $\begin{array}{c}-0.102 * * * \\
(-4.595)\end{array}$ & $\begin{array}{c}-0.235 * * * \\
(-7.250)\end{array}$ & $\begin{array}{c}(5.325) \\
-0.094 * * *\end{array}$ & $\begin{array}{c}(10.036) \\
-0.244 * * *\end{array}$ \\
\hline State Prosecution Index & $\begin{array}{c}-0.039 * * * \\
(-2.657)\end{array}$ & $\begin{array}{l}-0.038 * * \\
(-2.133)\end{array}$ & $\begin{array}{l}-0.046 * \\
(-1.696)\end{array}$ & $\begin{array}{c}(-4.192) \\
-0.055^{* * *}\end{array}$ & $\begin{array}{c}(-9.444) \\
-0.053 * * *\end{array}$ \\
\hline Fin Needs $s_{t-1}$ & $\begin{array}{l}0.061 * \\
(1.733)\end{array}$ & $\begin{array}{c}0.094 * * \\
(2.297)\end{array}$ & $\begin{array}{c}0.062 * * * \\
(2.696)\end{array}$ & $\begin{array}{l}(-3.020) \\
0.158 * *\end{array}$ & $\begin{array}{c}(-2.579) \\
-0.000\end{array}$ \\
\hline GDP & $\begin{array}{c}0.059 * * * \\
(4.911)\end{array}$ & $\begin{array}{c}0.086^{* * * *} \\
(5.841)\end{array}$ & $\begin{array}{c}0.016 \\
(0.717)\end{array}$ & $\begin{array}{c}(2.489) \\
0.091 * * *\end{array}$ & $\begin{array}{c}(-0.552) \\
0.024\end{array}$ \\
\hline GDP Growth\% & $\begin{array}{l}-3.571 * * * \\
(-10.055)\end{array}$ & $\begin{array}{c}-3.188 * * * \\
(-7.590)\end{array}$ & $\begin{array}{c}-6.577 * * * \\
(-9.394)\end{array}$ & $\begin{array}{c}(5.924) \\
-2.883 * * *\end{array}$ & $\begin{array}{c}(1.369) \\
-6.776^{* * *}\end{array}$ \\
\hline Non Profit Density & $\begin{array}{c}0.021 * * * \\
(8.023)\end{array}$ & $\begin{array}{c}0.024 * * * \\
(6.159)\end{array}$ & $\begin{array}{c}0.014 * * \\
(1.992)\end{array}$ & $\begin{array}{c}(-6.823) \\
0.021 * * *\end{array}$ & $\begin{array}{l}(-12.360) \\
0.025 * * *\end{array}$ \\
\hline Time Trend & $\begin{array}{c}0.196 * * * \\
(93.173)\end{array}$ & $\begin{array}{c}0.148 * * * \\
(64.669)\end{array}$ & $\begin{array}{c}0.327 * * * \\
(61.031)\end{array}$ & $\begin{array}{c}(5.673) \\
0.116^{* * *}\end{array}$ & $\begin{array}{c}(5.947) \\
0.338^{* * *}\end{array}$ \\
\hline Industry FE & Yes & Yes & Yes & $(55.103)$ & $(75.745)$ \\
\hline Constant & $\begin{array}{c}1.564 * * * \\
(9.957)\end{array}$ & $\begin{array}{c}0.623 * * * \\
(3.382)\end{array}$ & $\begin{array}{c}4.539 * * * \\
(6.911)\end{array}$ & $\begin{array}{c}-0.643 * * * \\
(-2.999)\end{array}$ & $\begin{array}{c}4.094 * * * \\
(15.737)\end{array}$ \\
\hline Observations & 76,123 & 47,492 & 28,578 & 46,781 & 46,336 \\
\hline Pseudo R-squared & 0.230 & 0.157 & 0.403 & 0.117 & 0.417 \\
\hline
\end{tabular}


In this table Industry Adjusted Trust is the difference between Trust and the median Trust value of that nonprofit's industry. In columns 3 and 4, Service Organization and Public Charities are calculated in an alternate manner as described in the text. The dependent is Over Spend Admin. Trust is based on a questionnaire administered by the World Values Survey for the period 2005-2009. All other variables are defined in Appendix A. Industry fixed effects (NTEE) are included and robust standard errors are calculated. $* * *, * * *$ represent significance at the $10 \%$, $5 \%$ and $1 \%$ level, respectively. 